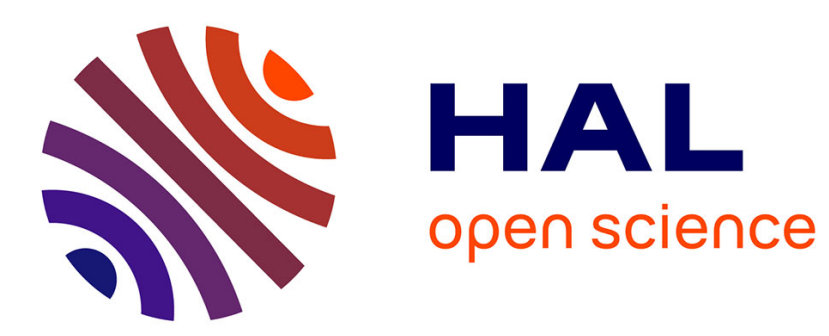

\title{
Side-effects of a systemic injection of linear polyethylenimine-DNA complexes
}

Patrice Chollet, Marie C. Favrot, A Hurbin, Jean-Luc Coll

\section{To cite this version:}

Patrice Chollet, Marie C. Favrot, A Hurbin, Jean-Luc Coll. Side-effects of a systemic injection of linear polyethylenimine-DNA complexes. The Journal of Gene Medicine, 2002. hal-02349471

\section{HAL Id: hal-02349471 \\ https://hal.science/hal-02349471}

Submitted on 8 Nov 2019

HAL is a multi-disciplinary open access archive for the deposit and dissemination of scientific research documents, whether they are published or not. The documents may come from teaching and research institutions in France or abroad, or from public or private research centers.
L'archive ouverte pluridisciplinaire HAL, est destinée au dépôt et à la diffusion de documents scientifiques de niveau recherche, publiés ou non, émanant des établissements d'enseignement et de recherche français ou étrangers, des laboratoires publics ou privés. 
Side effects of a systemic injection of linear polyethylenimine-DNA complexes.

Patrice Chollet, Marie C. Favrot, A. Hurbin and Jean-Luc Coll

Lung cancer research group, EMI INSERM 9924, Institute Albert Bonniot, Domaine de la Merci 38706 La Tronche, France.

Please send proofs and correspondence to J.L. Coll at the following address:

GRCP, Equipe INSERM 9924, Institute Albert Bonniot, Domaine de la Merci, 38706 La

Tronche, France

Phone: (33)4.76.54.95.53

Fax: (33)4.76.54.95.09

Email: Jean-Luc.Coll@ujf-grenoble.fr

SPONSORS: ARC (Association pour le Recherche Contre le Cancer), LCC (Ligue Contre le Cancer; Isère and Drôme), Emergence, GEFLUC, DRED, University J. Fourier, and INSERM

RUNNING TITLE: L-PEI-mediated toxicity

KEYWORDS: gene therapy, cationic vectors, lung, aggregation, toxicity, systemic administration. 


\section{ABSTRACT}

Background: Systemic administration of linear polyethylenimine-DNA complexes (L-PEI/DNA) results in transient expression of the transgene in the lung. In this study we analyzed the side effects associated with L-PEI-mediated transfection.

Methods: Mice of weight ranging from 16 to $25 \mathrm{~g}$ received increasing amounts of L-PEI/DNA intravenously. Gene expression was evaluated using luciferase as a reporter gene. Toxicity was

evaluated by monitoring the appearance of a shock after injection, the survival of the animals and the microscopic damages in the tissues. Adherence of blood cells on the endothelium was measured after immuno-staining of the CD1 lb positive cells. Anti-aggregant treatments were used in order to prevent the formation of thrombi.

Results: Increasing the quantity of L-PEI/DNA resulted in an important augmentation of the luciferase activity in the lung, but was associated with liver necrosis and death. Lethality was reached at lower doses in old mice than in the younger, suggesting also an influence of age. Transfection was associated with an augmentation of adhesion of CD11b positive cells on the endothelium, without evidence of lung injury. Anti-aggregant treatments (aspirin, EDTA, heparin or clopidogrel) decreased the L-PEI-mediated transfection, supporting the hypothesis that formation of thrombi was necessary for the blockade of DNA-complexes in the lung capillaries and subsequent transfection of lung cells.

Conclusion: This study demonstrates that L-PEI/DNA activates the lung endothelium and forms aggregates, a side effect linked to the transfection efficiency. In addition, the therapeutic dosewindow is too narrow for any clinical application. 


\section{INTRODUCTION}

Because of their small size and physical stability, L-PEI/DNA complexes display high transfection efficiency in vitro and in vivo (1-9). The particularly high capacity of L-PEI to deliver genes into the lungs of mice after an intravenous injection contributed to make of L-PEI a very promising vector for pulmonary diseases. However, some important limitations hindered the therapeutic development of this technique.

A first limitation comes from the observation that L-PEI-mediated gene expression is strongly restricted to the type II pneumonocytes, an epithelial cell type present in the alveoli. One prevailing hypothesis to explain the selective transfection of the lung is that L-PEI/DNA complexes are forming aggregates with blood components (7) and that these aggregates are blocked mechanically in the small capillaries of the lung. Despite the fact that it does not explain the selectivity toward type II pneumonocytes, this mode of functioning would not predispose the transfer of this technology to the clinic. A second limitation is due to the very short duration of expression of the transgene in the lung (8). Since expression is not sustained for more than one day, most of the applications and especially the correction of genetic abnormalities can not be approached by this method.

In order to determine whether or not these obstacles could be overcome, we focused our attention on the side effects associated with L-PEI/DNA intravenous injections. We present evidence that lung cell transfection is observed only when a close to lethal dose of L-PEI/DNA is injected. In the minutes following the injections the animal are shocked and some of them will eventually die. Transfection is associated with liver damages and lung endothelium activation. Furthermore, lung transfection is strongly decreased when animals are pretreated with anti-aggregant molecules supporting the hypothesis that lung transfection is linked to the formation of micro-thrombi. 


\section{MATERIALS AND METHODS}

Plasmid constructs and L-PEI/DNA complexes formation

Plasmid pCMV-Luc (8) was extracted with Qiagen Endo-free-Mega-prep columns (Qiagen, Chatsworth, CA).

Linear polymers of ethylenimine (L-PEI) with a mean molecular weight of $22 \mathrm{kDa}$ (Exgen 500; Euromedex, Souffleweyersheim, France) were used as transfection reagent. L-PEI/DNA complexes with a ratio of L-PEI nitrogen to DNA phosphate of 10 were prepared. These complexes were performed in a solution of $5 \% \mathrm{w} / \mathrm{v}$ glucose (final) in order to produce small particles (3). This was performed in a two step procedure as described hereafter for the preparation of a standard quantity of $50 \mu \mathrm{g}$ L-PEI/DNA complexes. In a first tube $15 \mu 10.1 \mathrm{M} \mathrm{L}$ PEI were diluted at RT with $60 \mu 1$ water and $25 \mu 1$ Glucose $25 \%$. In a second tube, $50 \mu 1$ DNA (1 $\mu \mathrm{g} / \mu \mathrm{l})$ were diluted with $25 \mu \mathrm{l}$ of water and $25 \mu \mathrm{l}$ glucose $25 \%$. The $100 \mu \mathrm{l}$ of L-PEI were then added quickly to the $100 \mu \mathrm{l}$ DNA and mixed thoroughly. After an incubation of $15 \mathrm{~min}$ at RT, the $200 \mu \mathrm{l}$ containing $50 \mu \mathrm{g} \mathrm{L-PEI/DNA} \mathrm{were} \mathrm{injected.} \mathrm{When} \mathrm{various} \mathrm{amounts} \mathrm{of} \mathrm{L-PEI/DNA} \mathrm{were}$ injected (from 20 to $150 \mu \mathrm{g}$ DNA), the final volume of the injected solution was kept constant to $200 \mu 1$. In these cases, the quantity of L-PEI was adjusted to the amount of DNA in order to maintain a ratio of 10 (L-PEI nitrogen to DNA phosphate).

Luciferase measurements. 
The luciferase assay was performed using the Luciferase Assay System (Promega) as recommended by the manufacturer. Briefly, tissues were extracted and cut in small pieces using a razor blade. One hundred $\mu 1$ of Cell Culture Lysis reagent for each $20 \mathrm{mg}$ of tissue were used to resuspend the extracts, which were then immediately frozen at $-20^{\circ} \mathrm{C}$. The following day, the samples were defrost and brought to RT. After a brief centrifugation, $10 \mu 1$ of extracts were mixed with $100 \mu 1$ of Luciferase Assay substrate and the luciferase activity was measured during $10 \mathrm{~s}$ on a photoluminometer (Promega). The concentration of protein was measured using the DC-comp Bio-Rad assay, and the luciferase activities were calculated as the number of $\mathrm{RLU} / 10 \mathrm{~s} / \mathrm{mg}$ of protein (RLU = Reference Light Unit). Using purified firefly luciferase in the same experimental conditions, we determined that $2 \mathrm{ng}$ of this enzyme produced $10^{8} \mathrm{RLU} / 10 \mathrm{~s}$.

Animal care and procedures

Female SWISS nude (IFFA-CREDO, Marcy l'Etoile, France) with weight ranging from 16 (4 weeks) to $25 \mathrm{~g}$ ( $\geq 10$ weeks) were injected rapidly (approximately $5 \mathrm{~s}$ ) in the tail vein using $1 \mathrm{ml}$ syringes with 29G x 1/2 needles (for insulin injection, Becton Dickinson, Meylan, France). At various times following the injection, the mice were killed by cervical dislocation. Heart, lung, spleen, liver, and kidneys were collected, washed with PBS and used for luciferase activity measurements.

For anti-aggregant treatments, $200 \mu \mathrm{g} / \mathrm{kg}$ aspirin (Synthelabo, France), or $5000 \mathrm{IU} / \mathrm{kg}$ heparin or $1 \mu \mathrm{g}$ EDTA (Sigma) in $200 \mu 1$ PBS were injected intravenously into $16 \mathrm{~g}$ mice. One hour later they were injected with $50 \mu \mathrm{g}$ L-PEI/DNA complexes. One day later the different organs were analyzed for their luciferase content. Note that other concentrations of aspirin were tried (100 and $400 \mu \mathrm{g} / \mathrm{kg}$ ) and produced similar results without any toxicity. 
In parallel, $16 \mathrm{~g}$ mice received $50 \mathrm{mg} / \mathrm{day} / \mathrm{kg}$ of clopidogrel (Plavix, Sanofi-Pharmacia, France) orally for 3 days, followed by one iv injection of $50 \mu \mathrm{g}$ L-PEI/DNA. One day later, luciferase expression was measured in the lung.

\section{CD11-b Immunolabeling}

Sixteen gram mice received an intravenous injection of L-PEI (15 $\mu 10.1 \mathrm{M}$ in $200 \mu 15 \%$ glucose), DNA (50 $\mu \mathrm{g}$ in $200 \mu 15 \%$ glucose), L-PEI-DNA (15 $\mu 10.1 \mathrm{M} \mathrm{L-PEI}+50 \mu \mathrm{g}$ DNA in $200 \mu 1$ 5\% Glucose) or glucose only. Three hours later, the mice were killed by cervical dislocation. Frozen sections of the lung were allowed to dry overnight at RT and fixed during 10 min with acetone at $-20^{\circ} \mathrm{C}$. Non-specific binding was avoided by incubating fixed tissues in $3 \%$ bovine serum albumin (BSA) in PBS (30 min at RT). Rat anti mouse CD11-b antibodies (Serotec, Oxford, England) were diluted at $1 / 50$ and incubated overnight at $4^{\circ} \mathrm{C}$. Secondary, peroxidaseconjugated anti rat immunoglobulins (DAKO, Copenhagen, Denmark) was diluted to $1 / 50$ and incubated for $1 \mathrm{~h}$ at RT. Diaminobenzidine tetrahydrochloride (Sigma, Saint Quentin Fallavier, France) was used as chromogenic substrate. A counterstaining of the nuclei was then performed using hematoxylin. Normal rat IgG at the same concentration as the primary antibodies served as a negative control. Sections were examined and counted on a Zeiss Axioskop microscope (40x magnification), using a triCCD camera (Sony) and a SAMBA 2005 software (SAMBA technologies, Grenoble). 


\section{RESULTS}

\section{L-PEI-mediated transfection of the lung is toxic.}

We have already shown that injection of $50 \mu \mathrm{g}$ of L-PEI/DNA complexes intravenously in $16 \mathrm{~g}$ mice (4-5 weeks old) results in a strong expression of the reporter gene in the lung (8). This is associated with toxicity, since most of the animals are shocked within the first 20 minutes following the i.v. injection.

In an attempt to determine the therapeutic dose-window of L-PEI/DNA (i.e. an efficient transfection of the lung but without shock), we injected increasing amounts of DNA complexes into $16 \mathrm{~g}$ mice (Figure 1). In these experiments, the L-PEI and DNA concentrations were increased proportionally in order to keep the same L-PEI/DNA ratio. As well, the injected volume and rate of injection were kept constant (200 $\mu$ l injected rapidly with a syringe). Luciferase expression in the lung started to be significant when at least $40 \mu \mathrm{g}$ L-PEI/DNA were injected (Figure 1). At lower doses, gene transfer was inefficient. Injection of $50 \mu \mathrm{g}$ L-PEI/DNA resulted in an increased expression of the transgene. At this dose, most of the animals were transiently shocked and 2 out of 42 of them died. Increasing the quantity of complexes to $100 \mu \mathrm{g}$ L-PEI/DNA had no dramatic influence on the lethality but was associated with the appearance of necrotic areas in the liver (Figure 2) and higher levels of gene transfer in the lung. When a dose of $150 \mu \mathrm{g} \mathrm{L-PEI} / \mathrm{DNA}$ was reached, all the treated animals died of the shock in the first 30 minutes (3/3). In older $25 \mathrm{~g}$ mice, lethality was observed as soon as $85 \mu \mathrm{g}$ L-PEI/DNA complexes were injected (25\%). This effect was even more pronounced at higher doses. All $25 \mathrm{~g}$ animals died of an injection of $100 \mu \mathrm{g}$ LPEI-DNA, suggesting that older animals were more sensitive to L-PEI/DNA (Table 1). 
We evaluated the efficacy of lung transfection in animals of growing sizes (between 4 and 30 weeks, from 16 to $25 \mathrm{~g}$ in weight) one day after an intravenous injection of $50 \mu \mathrm{g}$ L-PEI/DNA. As shown in Figure 3, luciferase expression was 600 times more elevated in the lung of young animals then in the older ones ( $2.8 \pm 0.410^{7}$ versus $4.7 \pm 1.910^{4} \mathrm{RLU} / \mathrm{mg}$ prot/10s). Thus, the usual dose of $50 \mu \mathrm{g} \mathrm{L}-\mathrm{PEI} / \mathrm{DNA}$ can produce significantly different results if the weight of the mice differs.

Histologically, no major tissue damage was noticed in the lung, spleen, kidneys, stomach, guts, skin and muscles (data not shown), but necrotic areas were always observed in the liver of animals which received high doses of L-PEI/DNA (Figure $2 \mathrm{~A}$ and B). In contrast, the lung did not present overt injury or infiltration (Figure $2 \mathrm{C}$ ), but an increased number of blood cells overlaying the endothelial surface was observed as soon as 30 min after L-PEI/DNA injection. This accumulation of lung cells was maximum at $3 \mathrm{~h}$ (Figure 2C) but still visible at $24 \mathrm{~h}$ (data not shown).

\section{L-PEI increases the adhesiveness of white blood cells}

We then quantified this phenomenon by counting the number of CD11-b positive cells in the lung of sixteen-gram mice treated with L-PEI, DNA, L-PEI/DNA or glucose only. Frozen sections of the lung were immuno-stained with an anti-CD11-b $3 \mathrm{~h}$ after injection. The results indicated that L-PEI alone or complexed with DNA can induce a 3 fold increased of the number of CD11-b positive cells including monocytes, granulocytes, natural killer (NK), some activated B lymphocytes and CD8 positive CTL on the surface of the lung endothelium (Figure 4).

\section{L-PEI/DNA-mediated gene transfer is influenced by anti- or pro-aggregant treatments.}


We suspected at first that the toxicity as well as the lung tropism of L-PEI/DNA complexes could be related to a mechanical block of the DNA complexes in the lung capillaries. To test this hypothesis, we pretreated $16 \mathrm{~g}$ mice with 4 anti-coagulants before iv injection of $50 \mu \mathrm{g} \mathrm{L}$ PEI/DNA.

Mice received aspirin, EDTA or heparin intravenously one hour before the L-PEI/DNA complexes. Each of these pre-treatments induced a significant decrease in the level of luciferase expression in the lung (Figure 5). Other animals received clopidogrel orally for 3 days, followed by one iv injection of $50 \mu \mathrm{g} \mathrm{L-PEI/DNA} \mathrm{(Figure} \mathrm{6).} \mathrm{Clopidogrel} \mathrm{had} \mathrm{a} \mathrm{lower} \mathrm{activity} \mathrm{than} \mathrm{aspirin}$ but still induced a significant decreased of expression in the treated $\left(9.3 \pm 0.3 \times 10^{6} \mathrm{RLU} / \mathrm{mg}\right.$ prot/10s) versus the control animals $\left(24.1 \pm 0.2 \times 10^{6} \mathrm{RLU} / \mathrm{mg} \mathrm{prot} / 10 \mathrm{~s} ; \mathrm{n}=5\right)$. 


\section{DISCUSSION}

Several studies have demonstrated that it is possible to transfer and express a foreign gene by injecting intravenously lipo- or polyplex $(1,10-15)$. L-PEI is one of the most efficient polycations when injected intravenously: as soon as two hours after L-PEI/DNA iv injection, lung cells and especially pneumonocytes are expressing the transgene $(8,9)$. Up to $5 \%$ of the lung cells are possibly transfected and can produce nano-grams of luciferase. Several other cationic vectors gave similar results in terms of rapidity of expression (16), transfected organ $(11,12,16-19)$, duration of gene expression and pattern of cytokine response (20-23). This suggests that cationicbased vectors have similar mode of functioning.

Several limitations still hinder the widespread application of systemic administration of non-viral vectors. Among them we can mention (i) the high selectivity of most, if not all, of the cationic vectors for the lung, (ii) the very transient aspect of transgene expression, too brief to be used for the correction of genetic abnormalities. In this study we present evidences that toxicity of cationic particles is also an important issue.

Cationic molecules must be toxic in order to be efficient and both properties can not be dissociated. Indeed, we show that L-PEI-mediated transfection of the lung requires the use of a close to lethal quantity of L-PEI/DNA complexes and that transfection is necessarily associated with the formation of thrombi. The toxicity of L-PEI-mediated transfection is obvious as soon as 15 min after injection of $50 \mu \mathrm{g} \mathrm{L-PEI/DNA.} \mathrm{A} \mathrm{shock} \mathrm{is} \mathrm{observed} \mathrm{in} \mathrm{the} \mathrm{following} \mathrm{minutes} \mathrm{but} \mathrm{is}$ overcome in $95 \%$ of the cases. Increasing the dose up to $100 \mu \mathrm{g}$ is associated with a powerful enhancement of the transfection, but most of the animals will suffer liver damages. In addition, the toxicity is observed at lower doses in older animals. Thus, the therapeutic dose-window is probably too narrow for any clinical application. 
So far, the prevailing hypothesis to explain the lung tropism of L-PEI/DNA complexes is that they are forming large aggregates with proteins such as IgM, fibrinogen, fibronectin and complement $\mathrm{C} 3$ and by interacting with erythrocytes $(7,24)$. These aggregates could be blocked in the lung capillaries (25), thus contributing to the overall toxicity. Pulmonary microvascular endothelial cells are known to play an active role in the events that lead to vascular damage in the inflammatory response. The endothelial surface, normally antithrombogenic, can respond to certain stimuli, generally injurious, by becoming strongly procoagulant. Such transformations of endothelial functions may be important for the entrapment and disposal of phagocytosed particles and may result in it's transient opening suggested by Zou et al. (9). This would be associated with an increased accessibility to epithelial cells. Once activated, the endothelium can bind blood cells more efficiently. Platelets may enhance the monocyte-endothelium interaction (26, 27). Our findings that L-PEI/DNA-mediated transfection can be inhibited by anti-aggregant treatments (aspirin, EDTA, heparin, clopidogrel) and that the number of CD11-b positive cells on the surface of the endothelium is increasing after L-PEI treatment strongly support the hypothesis of the transient activation and opening of the endothelium barrier.

Polycationic molecules like PEI can be covalently coupled to hydrophilic polymers like poly(ethylene glycol) (PEG) $(4,7)$ to transferrin $(24)$ or to antibodies $(4,28)$. By reducing the surface charge of the shielded particles the formation of aggregates is strongly decreased. This can result in a decreased expression of the reporter gene in the lung and an increased transfection of subcutaneous tumors (24). Antithrombogenic treatments are also associated with a decreased transfection of the lung, but without concomitant increased of the transfection of other organs including subcutaneous tumors (data not shown). Thus preventing the formation of thrombi does not produce the same effect than reducing the surface charge of the complexes. One hypothesis is that the shielding, but not antithrombic treatments, prolongs the circulation of the complexes in 
the blood, allowing their passive accumulation in organs with a disorganized vascularization like tumors. It seems reasonable to assume that these shielded particles will have a decreased toxicity and will thus be promising vectors. Nonetheless their biophysical properties, toxicity and efficiency will depend on the quality of the shielding compound(s) (4) and of the chemical methods used for the generation of these particles.

In conclusion, our study establishes that toxicity is a major concern when using polycationic particles to transfer DNA by systemic application, and that this toxicity is inherent to their mode of functioning. This will be helpful for the definition and generation of new molecules with increased performances and decreased toxicity.

\section{ACKNOWLEDGMENTS}

The authors thank Corine Tenaud, Sylvie Véranque and Dominique Desplanques for technical assistance. This work was supported by the ARC (Association pour le Recherche Contre

le Cancer), LCC (Ligue Contre le Cancer; Isère and Drôme), Emergence, GEFLUC and DRED. 


\section{LEGENDS}

Figure 1: Transfection efficiency is dose dependent. Nude mice of $16 \mathrm{~g}$ received the indicated amounts of L-PEI/DNA iv one day before sacrifice and measurement of the luciferase activity in their lungs. Representative experiment ( $\mathrm{n}=3$ per group) repeated 2 times.

Figure 2: L-PEI-mediated liver toxicity. A/ Liver section of a glucose treated animal. B/ Liver section of a $16 \mathrm{~g}$ mouse $24 \mathrm{~h}$ after injection of $100 \mu \mathrm{g} \mathrm{L-PEI/DNA} \mathrm{intravenously} \mathrm{(magnification:}$ x20 for A and B). C/ Adhesion of blood cells (indicated by arrowheads) on the lung endothelium (magnification: $\mathrm{x} 40$ ).

Figure 3: Transfection efficiency decreases with the weight of the mice. Mice of increasing

weight ( $\mathrm{n}=3$ per group) received $50 \mu \mathrm{g}$ of L-PEI/DNA iv one day before sacrifice and measurement of the luciferase activity in their lungs. As a whole, this experiment was performed only once with the 6 groups at the same time. These results were then repeated in independent experiments on a total of 42 sixteen grams mice and 21 mice of 25 grams.

Figure 4: CD11-b positive blood cells accumulate on the endothelium surface. Three hours after L-PEI/DNA injection (50 $\mu \mathrm{g}$ into a $16 \mathrm{~g}$ animal), the lungs were dissected and stained with an antiCD11-b antibody and counterstained with hematoxylin. The percentage of CD11b positive cells (brown) among the total lung cells (blue) was counted automatically using a Samba software after digitalization of the pictures. Eight animals per group were included in this study and 5 independent fields at a 40x magnification were counted for each animal. 
Figure 5: Aspirin, EDTA and heparin inhibit lung transfection. Sixteen gram mice ( $\mathrm{n}=3$ per group) were pre-treated with $200 \mathrm{mg} / \mathrm{kg}$ aspirin, $1 \mu \mathrm{g}$ EDTA or $5 \mathrm{IU} / \mathrm{g}$ heparin intravenously one hour before receiving $50 \mu \mathrm{g}$ L-PEI/DNA. One day later they were sacrificed and the luciferase activities present in the lungs were measured. This experiment was repeated three times with aspirin.

Figure 6: Clopidogrel inhibits lung transfection: Sixteen $g$ mice ( $\mathrm{n}=5$ per group) received 50 $\mathrm{mg} / \mathrm{Kg} /$ day clopidogrel or water only (control group) orally for 3 days before they were injected iv with $50 \mu \mathrm{g}$ L-PEI/DNA. One day later they were sacrificed and the luciferase activities present in the lungs were measured. In each organ the $\mathrm{p}$ value was always $<0.05$ using the Mann-Withney test (when the clopidogrel and control groups were compared). 


\section{REFERENCES}

1. Goula D, Benoist C, Mantero S, et al. Polyethylenimine-based intravenous delivery of transgenes to mouse lung. Gene Ther 1998 5: 1291-1295.

2. Boussif O, Lezoualc'h F, Zanta MA, et al. A versatile vector for gene and oligonucleotide transfer into cells in culture and in vivo: polyethylenimine. Proceding of National Academie of Science USA 1995 92: 7297-7301.

3. Goula D, Remy JS, Erbacher P, et al. Size, diffusibility and transfection performance of linear PEI/DNA complexes in the mouse central nervous system. Gene Therapy 1998 5: $712-717$

4. Erbacher P, Bettinger T, Belguise-Valladier P, et al. Transfection and physical properties of various saccharide, poly(ethylene glycol), and antibody-derivatized polyethylenimines (PEI). J Gene Med 1999 1: 210-222.

5. Labat-Moleur F, Steffan AM, Brisson C, et al. An electron microscopy study into the mechanism of gene transfer with lipopolyamines. Gene Therapy 1996 3: 1010-1017.

6. Abdallah B, Hassan A, Benoist C, et al. A powerful nonviral vector for in vivo gene transfer into the adult mammalian brain: polyethylenimine. Human Gene Therapy 1996 7: 1947-1954.

7. Ogris M, Brunner S, Kircheis R, et al. PEGylated DNA/transferrin-PEI complexes: reduced interaction with blood components, extended circulation in blood and potential for systemic gene delivery. Gene Therapy 1999 6: 595-605.

8. Coll JL, Chollet P, Brambilla E, et al. In vivo delivery to tumors of DNA complexed with linear polyethylenimine. Hum Gene Ther 1999 10: 1659-1666. 
9. Zou SM, Erbacher P, Remy JS, et al. Systemic linear polyethylenimine (L-PEI)-mediated gene delivery in the mouse. Journal of Gene Medicine 2000 2: 128-134.

10. Griesenbach U, Chonn A, Cassady R, et al. Comparison between intratracheal and intravenous administration of liposome-DNA complexes for cystic fibrosis lung gene therapy. Gene Ther 1998 5: 181-188.

11. Zhu N, Liggitt D, Liu Y, et al. Systemic gene expression after intravenous DNA delivery into adult mice. Science 1993 261: 209-211.

12. Li S, Rizzo MA, Battacharya S, et al. Characterization of cationic lipid-protamine-DNA (LPD) complexes for intravenous gene delivery. Gene Therapy 1998 5: 930-937.

13. Templeton NS, Lasic DP, Frederik PM, et al. Improved DNA:liposome complexes for increased systemic delivery and gene expression. Nature Biotechnologie 1997 15: 647652.

14. Liu Y, Mounkes LC, Liggitt HD, et al. Factors influencing the efficiency of cationic liposome-mediated intravenous gene delivery. Nat Biotechnol 1997 15: 167-173.

15. Stewart MJ, Plautz GE, Del Buono L, et al. Gene transfer in vivo with DNA-liposome complexes: safety and acute toxicity in mice. Hum Gene Ther 1992 3: 267-275.

16. Barron LG, Gagne L Szoka FC, Jr. Lipoplex-mediated gene delivery to the lung occurs within 60 minutes of intravenous administration. Hum Gene Ther 1999 10: 1683-1694.

17. Bragonzi A, Boletta A, Biffi A, et al. Comparison between cationic polymers and lipids in mediating systemic gene delivery to the lungs. Gene Ther 1999 6: 1995-2004.

18. Floch V, Delepine P, Guillaume C, et al. Systemic administration of cationic phosphonolipids/DNA complexes and the relationship between formulation and lung transfection efficiency. Biochim Biophys Acta 2000 1464: 95-103. 
19. Song YK, Liu F, Chu S, et al. Characterization of cationic liposome-mediated gene transfer in vivo by intravenous administration. Hum Gene Ther 1997 8: 1585-1594.

20. Tan Y, Li S, Pitt BR, et al. The inhibitory role of CpG immunostimulatory motifs in cationic lipid vector-mediated transgene expression in vivo. Human Gene Therapy 1999 10: $2153-2161$.

21. Li S, Wu S, Whitmore M, et al. Effect of immune response on gene transfer to the lung via systemic administration of cationic lipidic vectors. The american Journal of Physiology 1999 276: L796-804.

22. Whitmore M, Li S Huang L. LPD lipoplex initiates a potent cytokine response and inhibits tumor growth. Gene Therapy 1999 6: 1867-1875.

23. McLachlan G, Stevenson BJ, Davidson DJ, et al. Bacterial DNA is implicated in the inflammatory response to delivery of DNA/DOTAP to mouse lungs. Gene Ther 2000 7: $384-392$.

24. Kircheis R, Wightman L, Schreiber A, et al. Polyethylenimine/DNA complexes shielded y transferrin target gene expression to tumors after systemic application. Gene Ther 2001 8: $28-40$.

25. Bragonzi A, Dina G, Villa A, et al. Biodistribution and transgene expression with nonviral cationic vector/DNA complexes in the lungs. Gene Ther 2000 7: 1753-1760.

26. Theilmeier G, Lenaerts T, Remacle C, et al. Circulating activated platelets assist THP-1 monocytoid/endothelial cell interaction under shear stress. Blood 1999 94: 2725-2734.

27. Kuijper PH, Gallardo Torres HI, Houben LA, et al. P-selectin and MAC-1 mediate monocyte rolling and adhesion to ECM-bound platelets under flow conditions. J Leukoc Biol 1998 64: 467-473. 
28. O'Neill MM, Kennedy CA, Barton RW, et al. Receptor-mediated gene delivery to human peripheral blood mononuclear cells using anti-CD3 antibody coupled to polyethylenimine. Gene Ther 2001 8: $362-368$. 


\begin{tabular}{ccccc}
\cline { 2 - 5 } Weight & $\mathbf{5 0} \boldsymbol{\mu g}$ & $\mathbf{8 5} \boldsymbol{\mu g}$ & $\mathbf{1 0 0} \boldsymbol{\mu g}$ & $\mathbf{1 5 0} \boldsymbol{\mu g}$ \\
\hline & & & & \\
$\mathbf{1 6} \mathbf{g}$ & $2 / 42(4,76 \%)$ & $\mathrm{ND}$ & $0 / 6(0 \%)$ & $3 / 3(100 \%)$ \\
$\mathbf{2 5} \mathbf{g}$ & $0 / 21(0 \%)$ & $3 / 12(25 \%)$ & $3 / 3(100 \%)$ & $\mathrm{ND}$
\end{tabular}

Table 1: Percentage of dead mice 24 hours after injection of the indicated amount of DNA. DNA was mixed with 10 eq L-PEI in $200 \mu 15 \%$ glucose and injected rapidly in the tail vein. 